UDC 621.039

M. Alali,

V. Skalozubov, DSc, Prof.,

O. Chulkin, Phd, Assoc. Prof.,

T. Gablaiya

Odessa National Polytechnic University, 1 Shevchenko Ave., Odessa, Ukraine, 65044; e-mail: gntcod@te.net.ua

\title{
CONDITIONS FOR THE APPEARANCE OF HYDRAULIC SHOCK IN SOLAR INSTALLATION SYSTEMS
}

М. Алалі, В.І. Скалозубов, О.О. Чулкин, Т.В. Габлая. Умови виникнення гідроударів в системах сонячних установок. Гідроудари в системах сонячних установок можуть істотно впливати на їх надійність. Представлений метод визначення умов виникнення і наслідків гідроударів в системах сонячних установок, викликаних аперіодичною гідродинамічною нестійкістю внаслідок інерційності напірно-витратної характеристики насосів. Визначено критерії умов виникнення гідроударів у типових схемах систем сонячних установок при запуску насосів в залежності від часу «запізнювання» реакції напірно-витратної характеристики і часу досягнення встановленої стану теплоносія. Отримано рішення для максимальної амплітуди тиску при гідроударах, яке на відміну від відомої формули Н.Є. Жуковського враховує конструкційно-технічні характеристики гідравлічної схеми систем сонячних установок, інерційність напірно-витратної характеристики насосів, перехід кінетичної енергії гальмування теплоносія у енергію імпульсу тиску гідроудару. Виникнення гідродинамічних ударів $є$ наслідком аперіодичної і коливальної гідродинамічної нестійкості в системах сонячних установок. Аперіодична гідродинамічна нестійкість може виникнути в перехідних режимах (наприклад, пуску насоса). Коливальна гідродинамічна нестійкість може виникнути в робочих режимах. В обох випадках виникнення гідродинамічної нестійкості викликано інерційністю напірно-витратної характеристики насосів. Під інерційністю напірно-витратної характеристики насосів мається на увазі запізнення в часі реакції напірно-витратної характеристики насосів на зміну гідродинамічних параметрів потоку. Отримані результати можуть бути використані при проектуванні насосів систем сонячних батарей для усунення причин і наслідків гідроударів на працездатність і надійність.

Ключові слова: гідроудари, системи сонячних установок, інерційність насосів, аперіодична гідродинамічна нестійкість

M. Alali, V. Skalozubov, O. Chulkin, T. Gablaiya. Conditions for the appearance of hydraulic shock in solar installation systems. Hydraulic shock (HS) in solar installation can significantly affect on their reliability. A method for determining the conditions and consequences of hydraulic shock caused by aperiodic hydrodynamic instability due to inertia of pump head-flow is presented. Criteria of conditions of Hydraulic shock when starting pumps in standard circuits of solar installations depending on the delay time of the head-flow and time to reach a coolant steady state are found. A solution was found for the maximum pressure amplitude under hydraulic shock. Unlike the well-known Jukowsky formula, it considers the design and technical characteristics of the hydraulic circuit of solar installations, the inertia of head-flow characteristic of pump, and transition of kinetic energy of coolant stagnation to energy of pressure pulse of hydraulic shock. Hydraulic shock is a consequence of aperiodic and oscillatory hydrodynamic instability in solar installations. Aperiodic hydrodynamic instability may occur in transient conditions (for example, starting the pump). Oscillatory hydrodynamic instability may occur in operating conditions. Hydrodynamic instability is caused by inertia of head-flow characteristic of pumps in both cases. Inertia of headflow characteristic of pumps is mean a time delay of the response of head-flow characteristic of pumps to change the flow hydrodynamic parameters. We can use found results to eliminate causes and consequences of HS for operability and reliability of pump designs of solar installations.

Keywords: hydraulic shock, solar installation systems, inertia of pumps, hydrodynamic instability

Introduction. Typical scheme of solar installation systems (SIS) represents the circulation loop of pipelines, including various heating equipment: solar panels, pumps, heat exchangers and valves (Fig. 1). The reliability of an SIS substantially depends on the conditions and consequences of the occurrence of hydraulic shock (HS). HS is a phenomenon that is accompanied by a pulsed hydrodynamic effect on equipment and elements of piping systems, caused by abrupt deceleration of the flow. In the case of a hydraulic shock, the kinetic energy of the flow passes into the energy of the pressure amplitude of the hydrodynamic effect. The emergence of hydraulic shock leads to a decrease in the reliability of the required heat transfer of the SIS, as well as to premature wear of the SIS equipment.

Analysis of recent research. The issues of HS modeling in systems of power equipment were studied in [1], [2 - 9] and others. Most of the papers addressed the issues of HS modeling during deceleration of flows on the armature. To estimate the maximum pressure amplitude $\left(\Delta P_{w m}\right)$, the wellknown Zhukovsky formula is traditionally used:

\section{DOI: 10.15276/opu.3.56.2018.05}

(C) 2018 The Authors. This is an open access article under the CC BY license (http://creativecommons.org/licenses/by/4.0/). 


$$
\Delta P_{w m}=\rho \Delta V c_{m},
$$

where $\rho$ - is the flux density;

$\Delta V$ - the difference in flow rates before and after HS;

$c_{m}$ - the speed of propagation of the front pressure increase.

However, formula (1) does not determine the causes and conditions for the occurrence of HS, but determines only their consequences. In addition, the problems of the occurrence of HS in various types of thermos hydro dynamic instability are considered insufficiently.

The inertia of the pressure-flow characteristics of the pumps can be the cause of the thermalhydrodynamic instability. In [3], it was shown that the inertia of the pressure-flow characteristics (PFC) of pumps may be a possible reason for the HS:

$$
\Delta P_{p u}=f(G),
$$

where $\Delta P_{p u}$ - pump head pressure;

$G$ - mass flow in the circulation circuit.

PFC is determined by the design and technical characteristics of the pumps. Under the inertia of PFC is meant the "delay" in the reaction time of the PFC to changes in consumption. The maximum lag time of the initial PFC ( $\Delta t$ ) reaction is determined by the total length of the circulation loop $L$, as well as the average velocity of the coolant in the circulation loop:

$$
\Delta t=\rho \Pi_{\max }\left[\frac{L}{G(t)}\right],
$$

where $\rho$ - the density of the coolant;

$\Pi_{\max }$ - the maximum flow area of the contour.

A consequence of the inertia of the PFC at the start-up of pumps is aperiodic hydrodynamic instability, accompanied by a pulse change in pressure and flow rate [3].

Therefore, the pressing issue of ensuring the reliability of the SIS is the analysis of the conditions for the occurrence and consequences of the HS, caused by the inertia of PFC during the start-up of pumps.

The aim of the work is to apply a method for determining the conditions of occurrence and effects of HS in solar installation systems caused by aperiodic hydrodynamic instability due to the inertia of the pressure-flow characteristics of pumps.

Materials and research methods. A method has been developed for determining the conditions for the occurrence and consequences of HS in solar installations caused by aperiodic hydrodynamic instability due to the inertia of the pressure-flow characteristics of pumps.

The main provisions of the method of determining the conditions of hydraulic shock in solar installation systems. The main provisions of the method and the results of the HS simulation when starting solar installation pump are as follows:

1. The design scheme for the conditions of occurrence of a HS is shown in Fig. 1.

2. At pump start-up, the conditions for the occurrence of a discharge condition are determined by the aperiodic hydrodynamic instability (AGI) caused by the delay (inertia) of the PFC pump response (1) to changes in flow conditions in the solar system circuit.

3. In the transient mode of starting the pump at the initial moment of time $(t=0)$, the maximum pres-

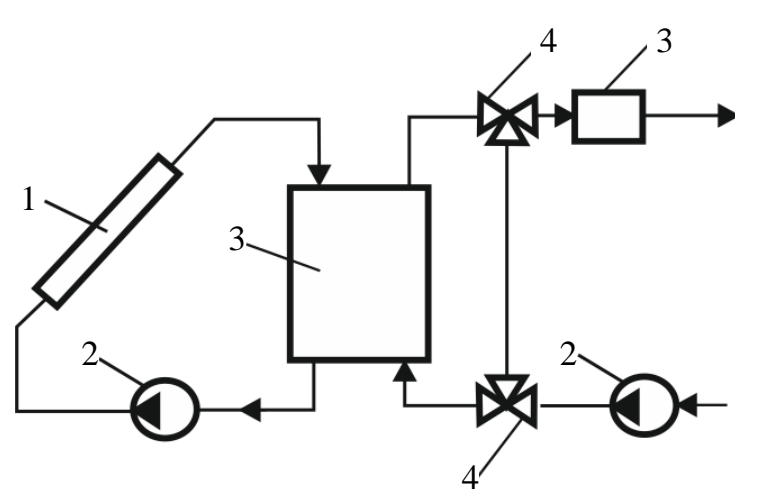

Fig. 1. Typical thermal scheme of a solar installation for hot water: 1 - solar battery; 2 pumps; 3 - heat exchangers; 4 - fittings 
sure ( $\Delta P_{\text {pum }}$ ), and the flow rate in $G_{(t=0)}=0$ (Fig. 2). If the time to reach the steady state $\left(\Delta t_{\mathrm{s}}\right)$ is greater than $\Delta t$, then a further $G$ increase leads to a $\Delta P_{p u}$ decrease in accordance with the design PFC of the pump (Fig. 2). In steady working condition:

$$
G\left(t \geq \Delta t_{s}\right)=G_{s} ; \Delta P_{\text {pus }}\left(G_{s}\right)=\Delta P_{g}\left(G_{s}^{2}, h, L\right),
$$

where $\Delta P_{g}$ - is the pressure drop across the hydraulic resistances and in the areas of the circuit with leveling height $h$;

$\Delta t_{\mathrm{s}}$ - time to reach steady-state (stationary) state; $G_{s}$ - flow rate in the circuit at steady state.

If $\Delta t \geq \Delta t_{s}$, then the pressure of the pump retains its initial value ( $\Delta P_{\text {pum }}$ ) until time $t=\Delta t$. In this case, the flow continues to increase in the time interval $\Delta t_{s}<t \leq \Delta t$ (Fig. 2). In this time interval, the hydrodynamic SIS is in an unstable state, since $G>G_{s}$ and $\Delta P_{\text {pu }}=\Delta P_{\text {pum }}>\Delta P_{\text {pus }}$. With $t>\Delta t$, the hydrodynamic parameters $\left(G, \Delta P_{p u}\right)$ go into a stable working state (3), which leads to a pulsed deceleration of the coolant flow and the occurrence of HS due to AGI. In this case, the kinetic energy of deceleration of

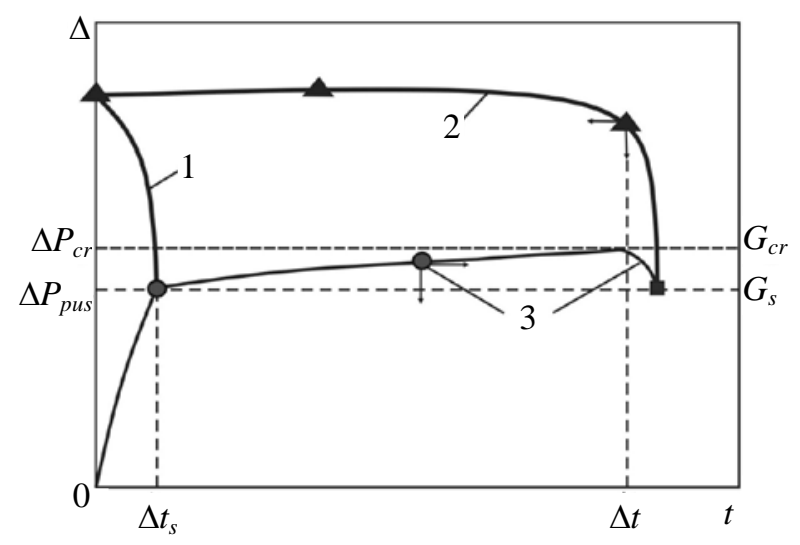

Fig. 2. Conditions for the occurrence of HS in the transitional mode of starting SIS pumps: 1 - pump head $\left(\Delta P_{p u}\right)$ with $\Delta t_{s}>\Delta t ; 2-\Delta P_{\text {pu }}$ pumps with $\Delta t \geq \Delta t_{s} ; 3-$ coolant flow rate $(G)$ the flow of the coolant turns into energy of the amplitude of HS pressure.

The equations of motion and energy conservation in the transitional mode of starting the SIS pumps can be represented as:

$$
\begin{gathered}
\frac{L}{\Pi} \frac{d G}{d t}=\Delta P_{p u m}+\int_{0}^{t} f^{\prime}(\tau-\Delta t) \cdot \frac{d G}{d \tau} \cdot d \tau-\frac{\xi_{R}(L)}{\rho \Pi^{2}} \cdot G^{2}+\rho g h \operatorname{sign}(h), \\
\frac{d}{d t}\left[\frac{G^{2}}{2 \rho \Pi^{2}}+\rho i\right]=0, \\
G(t=0)=0 ; \quad i(P, t=0)=i_{0}\left(P_{0}\right),
\end{gathered}
$$

where $\xi_{R}$ - the total coefficient of hydraulic resistance of the SIS circuit;

$i$ - specific (per unit mass) enthalpy of the coolant;

$P$ - pressure at the entrance to the SIS.

$$
\begin{aligned}
& \operatorname{sign}(h)=\left\{\begin{array}{l}
1, \text { when lowering the flow; } \\
-1 \text {, with upward flow movement, }
\end{array}\right. \\
& \text { PFC gradient: } f^{\prime}(\tau-\Delta t)=\left\{\begin{array}{l}
0, \tau<\Delta t \\
\frac{d \Delta P_{p u}}{d G} \cdot \frac{d G}{d \tau} \geq \Delta t
\end{array}\right.
\end{aligned}
$$

Criterion of conditions for the occurrence of HS due to AGI:

$$
K_{\mathrm{WHA}}=\frac{\Delta t}{\Delta t_{s}}>1 \text {. }
$$

The maximum pressure WH amplitude due to AGI follows from the equation (5): 


$$
\Delta P_{\mathrm{WM}}=\int_{0}^{t_{c}} \frac{d P}{d t} d t=-\frac{\int_{0}^{t_{c}} G \cdot \frac{d G}{d t} \cdot d t}{\rho \Pi^{2}\left(\rho \frac{d i}{d P}+\frac{i}{c_{i}^{2}}\right)},
$$

where $t_{c} \approx L / c_{m}$ - the time of the pulse,

$c_{i}$ - the speed of sound in the liquid coolant.

Unlike the well-known formula (1), equation (9) takes into account the structural and technical parameters of SIS, the inertia of the PFC pumps and the conditions for the transition of the kinetic energy of the flow deceleration into the energy of the HS pressure amplitude.

In the general case, the solution of the system of equations (3) - (9) is possible by numerical methods.

The simplified approach to determining the $K_{\mathrm{wH}}$ criteria for the conditions of occurrence of $\mathrm{HS}$ due to AGI is based on the following conservative assumptions (i.e., with a "margin" for the conditions of HS):

$$
\Delta t \approx \frac{\rho \prod_{\max } L}{G_{s}} ; G \frac{d G}{d t} \approx G_{c r} \frac{G_{c r}-G_{s}}{\Delta t_{s}},
$$

where $G_{c r}(\Delta t)$ - maximum (critical) flow at time $t=\Delta t$ (Fig. 2), provided $d G / d t<0$.

Under such assumptions, from equations (4), (5), it follows:

$$
\begin{gathered}
\Delta t_{\mathrm{s}} \sim \frac{1}{2 \sqrt{K_{p u} \cdot K_{\xi}}} \cdot \ln \left[\frac{\sqrt{K_{p u}}+G_{\mathrm{s}} \sqrt{K_{\xi}}}{\sqrt{K_{p u}}-G_{\mathrm{s}} \sqrt{K_{\xi}}}\right], \\
K_{\mathrm{WHA}} \approx \frac{2 \rho \Pi_{\max } L \cdot \sqrt{K_{p u} \cdot K_{\xi}}}{G_{s} \cdot \ln \left[\frac{\sqrt{K_{p u}}+G_{\mathrm{s}} \sqrt{K_{\xi}}}{\sqrt{K_{p u}}-G_{s} \sqrt{K_{\xi}}}\right]} \\
\Delta P_{\mathrm{WMA}} \approx \frac{G_{c r}\left(G_{c r}-G_{s}\right)}{\rho \Pi^{2}\left(\rho \frac{d i}{d P}+\frac{i}{c_{l}^{2}}\right)},
\end{gathered}
$$

where $K_{p u}=\Delta P_{p u m} \cdot \frac{\Pi}{L}$;

$$
\begin{aligned}
K_{\xi} & =\frac{\xi_{R}}{\rho \Pi \cdot L} ; \\
G_{c r} & =\rho \Pi \cdot L \sqrt{\frac{K_{p u}}{K_{\xi}}} \cdot\left(\frac{\exp \left(K_{c r}\right)-1}{\exp \left(K_{c r}\right)+1}\right) ; \\
K_{c r} & =\frac{2 \sqrt{K_{p u} \cdot K_{\xi}} \rho \Pi L}{G_{s}} .
\end{aligned}
$$

Under conditions:

$K_{\text {WHA }}<1-$ HS is missing due to AGI,

$K_{\text {WHA }} \geq 1$ - there is a hydraulic shock due to AGI.

Analysis of the obtained solutions showed that, provided:

$$
\frac{\Delta P_{\text {pum }}}{\Delta P_{\mathrm{s}}}<1.3,
$$

maximum pressure amplitudes of HS do not exceed $10 \%$ of the pressure in the SIS. 


\section{Conclusions.}

1. A method for determining the conditions of occurrence and the effects of hydraulic shock in solar systems caused by aperiodic hydrodynamic instability due to the inertia of the pressure-flow characteristics of pumps is presented.

2. The criteria for the occurrence of hydraulic shock in typical schemes of solar systems when starting pumps are determined depending on the time delay of the reaction of the pressure-flow characteristics and the time to reach the steady state of the coolant.

3. A solution was obtained for the maximum pressure amplitude with hydraulic impacts, which, unlike the well-known Zhukovsky formula, takes into account the design and technical characteristics of the hydraulic circuit of solar systems, the inertia of the pressure-flow characteristics of the pumps, the transition of the kinetic braking energy of the hydraulic shock.

4. On the basis of the obtained results, practical recommendations for the design of the pressureflow characteristics of pumps have been developed, which allow prevent the conditions for the occurrence of HS, which significantly affect the reliability and performance of solar installation systems.

\section{Література}

1. Скалозубов В.И., Чулкин О.А., Пирковский Д.С. Обзорный анализ условий и последствий гидродинамических ударов в оборудовании и трубопроводах систем, важных для безопасности ядерных энергетических установок. Ядерна енергетика та довкілля. 2018. № 1(11). С. 37-43.

2. Ghidaoui M.S. Fundamental Theory of Water Hammer. Special Issue of the Urban Water I. 2001. № 1(2). P. 71-83.

3. Скалозубов В.И., Чулкин О.А., Пирковский Д.С. Гидроудары вследствие теплогидродинамической неустойчивости : LAP Lambert Academic Publishing. 2018. 56 с.

4. Королев А.В., Ищенко А.П., Ищенко О.П. Исследование гидравлических ударов при заполнении системы компенсации давления в WWER. Известия высших учебных заведений. Энергетика. 2017. № 5. C. 459-469.

5. Guinot V. Rieman. Solvers for water hammer simulations by godunov method. Numerical methods in engineering. 2002. P. 851-870. DOI: https://doi.org/10.1002/1097-0207(20001110)49:7<851::AIDNME978>3.0.CO;2-\%23.

6. Ghidaoui M.S., Zhau M., McInnis D.F., Axworthy D.H. A Review of Water Hammer Theory and Practice. Applied Mechanics Reviews. 2005. № 58. Р. 49-76.

7. Корольов О.В., Чжоу Хуіюй. Динамічні погашувачі коливань тиску у насосних системах. Праці Одеського політехнічного університету. 2016. № 1(48). С. 35-41.

8. Безруков А.Ю., Лисенков Е.А., Селезнев А.В. Анализ возможности гидроударов в первом контуpe реакторов WWER. OAO ОКБ «Гидропресс»: сб. трудов международной научно-технической конференции по повышению безопасности АЭС. Подольск. 2009 г.

9. Мазуренко А.С., Скалозубов В.И., Козлов И.Л., Пирковский Д.С., Чулкин О.А. Определение условий возникновения гидроударов в гидросистемах. Проблемы региональной энергетики. 2017 г. №2(34) C. 99-105. URL: http://journal.ie.asm.md/ru/contents/electronni_jurnal-234-2017.

\section{References}

1. Skalozubov, V.I., Chulkin, O.A., \& Pirkovskiy, D.S. (2018). Overview analysis of the conditions and effects of hydrodynamic impacts on equipment and piping systems important to the safety of nuclear power plants. Nuclear Power and the Environment. 1(11), 37-43.

2. Ghidaoui, M.S. (2001). Fundamental Theory of Water Hammer. Special Issue of the Urban Water I. 1(2), 71-83.

3. Skalozubov, V.I., Chulkin, O.A., \& Pirkovsky, D.S. (2018). Water hammer due to thermalhydrodynamic instability. LAP Lambert Academic Publishing, 56.

4. Korolev, A.V., Ishchenko, A.P., \& Ishchenko, O.P. (2017). The study of hydraulic shocks when filling the pressure compensation system in WWER. Proceedings of the higher educational institutions. Energy. 5, 459-469.

5. Guinot, V. Rieman (2002). Solvers for Water Hammer Simulations by Godunov Method. Numerical methods in engineering, 851-870. DOI: https://doi.org/10.1002/1097-0207(20001110)49:7<851::AIDNME978>3.0.CO;2-\%23. 
6. Ghidaoui, M.S., Zhau, M., McInnis, D.F., \& Axworthy D.H. (2005). A Review of Water Hammer Theory and Practice. Applied Mechanics Reviewz, 58, 49-76.

7. Korolev, O.V., \& Zhou Hui Yu. (2016). Dynamic Damper Pressure Fluctuation in the Pumping Systems. Proceeding of Odessa Polytechnic university, 1(48), 35-41.

8. Bezrukov, A.Yu., Lisenkov, E.A., \& Seleznev, A.V. (2009). Analysis of the possibility of water hammer in the first loop of WWER reactors. OKB Gidropress OJSC: Proceedings of the International Scientific and Technical Conference on improving the safety of nuclear power plants. Podolsk.

9. Mazurenko, A.S., Skalozubov, V.I., Kozlov, I.L., Pirkovskiy, D.S., \& Chulkin, O.A. (2017). Determining the conditions for the hydraulic impacts emergence at hydraulic systems. Problemele energeticii regionale. 2(34), 99-105. Retrieved from: http://journal.ie.asm.md/ru/contents/ electronni_jurnal-234-2017.

Алалі Мохаммад; Alali Mohammad, ORCID: https://orcid.org/0000-0003-4052-9331

Скалозубов Володимир Іванович; Skalozubov Volodymyr, ORCID: https://orcid.org/0000-0003-2361-223X

Чулкін Олег Олександрович; Chulkin Oleg, ORCID: https://orcid.org/0000-0001-5048-4545

Габлая Таїсія Володимирівна; Gabalaya Taisiya, ORCID: https://orcid.org/0000-0003-3184-5674

Received November 13, 2018

Accepted December 7, 2018 